\title{
sciendo
}

Transport and Telecommunication, 2020, volume 21, no. 3, 203-210

Transport and Telecommunication Institute, Lomonosova 1, Riga, LV-1019, Latvia

DOI 10.2478/ttj-2020-0016

\section{USING AN ADAPTED ZACHMAN FRAMEWORK FOR ENTERPRISE ARCHITECTURE IN THE DEVELOPMENT OF AN INDUSTRY METHODOLOGY OF INTEGRATED SUPPLY CHAIN PLANNING}

\author{
Victor Sergeev ${ }^{1}$, Vitaly Solodovnikov ${ }^{2}$ \\ ${ }^{1,2}$ Higher School of Economics, \\ Moscow, Russia, Shabolovka Str., 26, Bld., \\ vsergeev@hse.ru,vsolodovnikov@hse.ru
}

\begin{abstract}
Trends in the digitalization of business open up opportunities for the use of fundamental approaches to the development of enterprise architecture in the creation of appropriate methodologies.

The article discusses the approach to the use of adapted Zachman framework for enterprise architecture as a basis for the systematization and structuring of the industry methodologies of integrated supply chain planning based on SCOR model. A practical example of using the proposed approach for description of one of the target processes - tactical supply chain planning is considered.
\end{abstract}

Keywords: Enterprise architecture, Zachman framework, SCOR, SCM

\section{Introduction}

The solution of an important economic problem - the development of an industry methodology of integrated supply chain planning of ferrous metallurgy companies implies the definition of its structure. This term directly refers to the concept of methodology (Solodovnikov, 2017).

One of many definitions of methodology is "methodology (from "method" and "logic") - the doctrine of the structure, logical organization, methods and means of activity." In the philosophical encyclopedia: "methodology - a system of principles and methods of organization and construction of theoretical and practical activities, as well as the doctrine of this system."

As can be seen from the definitions above, the methodology considers the organization of activities. To organize an activity means to organize it into a complete system with well-defined characteristics, logical structure and process of its implementation - a temporary structure.

The practical aspects of implementing integrated supply chain planning are closely related to information technology and in general to the design of enterprise architecture.

Thus, it is logical that existing approaches to defining the enterprise architecture are proposed to be used when developing the structure of the methodology of integrated supply chain planning of ferrous metallurgy companies.

The purpose of the paper is to present the approach to the use of adapted Zachman framework for enterprise architecture as a basis for the systematization and structuring of the industry methodologies of integrated supply chain planning. A practical example of using the proposed approach for description of one of the target processes - tactical supply chain planning of ferrous metallurgy company is considered.

\section{Main part}

The term enterprise architecture was first mentioned in 1987 in an article by Zachman (1987). In this article, Zachman outlined both the challenge and vision of corporate architectures that have defined the direction of development of a new field of knowledge for the next decades (Sessions, 2007a, Harmon, 2007). To date, a large number of approaches have been developed to describe the architecture of the enterprise (Shteyngart and Burmistrov, 2016), but many of them use in one form or another the classical basis laid by Zachman at the end of the last century.

According to Zachman, a holistic approach to system architecture that addresses key issues from all key perspectives can significantly increase business value and flexibility. This multi-perspective 
approach to system architecture originally called the information systems architecture framework was soon renamed the enterprise architecture framework by Zachman.

In his next work (Zachman and Sowa, 1992), Zachman proposed an extended framework for building an enterprise architecture, named after the author.

Zachman originally defined this framework as a taxonomy (classifier), i.e. it is a scheme for organizing architectural artifacts (project documents, specifications, models), which simultaneously represents the target user of the artifact (for example, the business owner) and the problem area (for example, working with data).

Zachman noted that "the enterprise architecture model is simply a logical framework for classifying and organizing enterprise descriptive representations that are important for enterprise management as well as for the development of enterprise systems."

In computer science, the Zachman enterprise architecture framework is referred to as a specialized (subject-oriented) ontology. In this case, the ontological model is understood as a conceptualized representation of information (a description of a set of objects and relationships between them) about any field of activity, presented in electronic form (Gorshkov, 2016). In other words, ontology in computer science is a purposeful attempt to formalize a certain area of knowledge using a conceptual scheme. I.e. information ontologies are always created with specific goals (solving design problems) and are evaluated more in terms of applicability than completeness.

However, as Sessions (2007a) notes, a lot of followers of the Zachman framework see it as an interdisciplinary concept whose impact goes far beyond it. O'Rourke, Fishman, and Selkow in their book (2003) say the following: "over time, you will find that the framework exists in everything you do, not just in it projects. When you fully understand the structure, you can become more effective in everything you do. This applies to everything. And this statement is not frivolous."

Zachman himself later told Roger Sessions in an interview:"...the framework scheme has been around for thousands of years, and I'm sure it will be around for a few thousand more years. What is changing is our understanding of the framework and how it can be applied to enterprise design and development (Sessions, 2007b)." The General view of the Zachman framework is shown in table 1.

Table 1. General view of Zachman framework

\begin{tabular}{|l|l|l|l|l|l|l|}
\hline & Why & How & What & Who & Where & When \\
\hline Contextual & Goal List & Process List & Material List & $\begin{array}{l}\text { Organizational } \\
\text { Unit \& Role List }\end{array}$ & $\begin{array}{l}\text { Geographical } \\
\text { Locations List }\end{array}$ & $\begin{array}{l}\text { Event List } \\
\text { Conceptual }\end{array}$ \\
$\begin{array}{lllll}\text { Goal } \\
\text { Relationship }\end{array}$ & Process Model & $\begin{array}{l}\text { Entity } \\
\text { Relationship } \\
\text { Model }\end{array}$ & $\begin{array}{l}\text { Organizational } \\
\text { Unit \& Role } \\
\text { Relationship } \\
\text { Model }\end{array}$ & $\begin{array}{l}\text { Locations } \\
\text { Model }\end{array}$ & Event Model \\
\hline Logical & $\begin{array}{l}\text { Rules } \\
\text { Diagram }\end{array}$ & $\begin{array}{l}\text { Process } \\
\text { Diagram }\end{array}$ & $\begin{array}{l}\text { Data Model } \\
\text { Diagram }\end{array}$ & $\begin{array}{l}\text { Role } \\
\text { Relationship } \\
\text { Diagram }\end{array}$ & $\begin{array}{l}\text { Locations } \\
\text { Diagram }\end{array}$ & $\begin{array}{l}\text { Event } \\
\text { Diagram }\end{array}$ \\
\hline Physical & $\begin{array}{l}\text { Rules } \\
\text { Specification }\end{array}$ & $\begin{array}{l}\text { Process } \\
\text { Function } \\
\text { Specification }\end{array}$ & $\begin{array}{l}\text { Data Entity } \\
\text { Specification }\end{array}$ & $\begin{array}{l}\text { Socation } \\
\text { Specification }\end{array}$ & $\begin{array}{l}\text { Event } \\
\text { Specification }\end{array}$ \\
\hline Detailed & Rules Details & $\begin{array}{l}\text { Process } \\
\text { Details }\end{array}$ & Data Details & Role Details & $\begin{array}{l}\text { Location } \\
\text { Details }\end{array}$ & Event Details \\
\hline
\end{tabular}

The Zachman framework is a two-dimensional classification scheme whose cells are intersections of elements of two historical classifications. The first classification includes a set of simple questions: why, how, what, who, where, when. Each of the questions implies the following: why-a goal that depends on this level; how-a method; what-data; who - an organizational unit; where - location characteristics; when-time characteristics. The second classification stems from the philosophical concept of reification, that is, the implementation of abstract ideas in life: contextual, conceptual, logical, physical, details of implementation.

The original Zachman framework was adapted for the purpose of developing a methodology of integrated supply chain planning of ferrous metallurgy enterprises (see table 2).

The contextual level was deleted since from the point of view of developing the industry methodology of integrated supply chain planning, this level looks redundant and may well be consolidated with the conceptual level. Thus, in the framework of the new scheme, the analyst does not start with the classical approach of building an ontological model - drawing up a list of objects, but already forms conceptual ideas, the customer of which is the institutional level (i.e., senior management, owners). 
Within the "when" table column, events are also not disclosed in accordance with the ontological approach, starting from the top level, where a list of events is compiled without reference to time, and then within the next levels, their relationship is determined and time-bound, taking into account the existing constraints. Instead, the author proposed a separate implementation level, which describes the implementation options of the activity under consideration, including the implementation plan. At the same time, the "when" column for other levels describes the time characteristics of the activity under consideration.

Table 2. Upgraded Zachman framework for describing the industry methodology of integrated supply chain planning

\begin{tabular}{|c|c|c|c|c|c|c|}
\hline $\begin{array}{l}\text { Levels/ } \\
\text { Questions }\end{array}$ & Why & How & What & Who & Where & When \\
\hline Conception & $\begin{array}{l}\text { Business } \\
\text { goals/objectives }\end{array}$ & $\begin{array}{l}\text { Text description } \\
\text { and graphic } \\
\text { models }\end{array}$ & $\begin{array}{l}\text { Key data } \\
\text { flows }\end{array}$ & $\begin{array}{l}\text { Responsible } \\
\text { departments }\end{array}$ & $\begin{array}{l}\text { Leading } \\
\text { company }\end{array}$ & $\begin{array}{l}\text { Planning } \\
\text { horizon and } \\
\text { interval }\end{array}$ \\
\hline Processes & $\begin{array}{l}\text { Goals/objectives } \\
\text { of the process }\end{array}$ & $\begin{array}{l}\text { Process } \\
\text { description }\end{array}$ & $\begin{array}{l}\text { Description of } \\
\text { entities }\end{array}$ & $\begin{array}{l}\text { Departments } \\
\text { participating in } \\
\text { the process }\end{array}$ & Supply chain & $\begin{array}{l}\text { Main steps of } \\
\text { the process }\end{array}$ \\
\hline Logical & $\begin{array}{l}\text { Model } \\
\text { requirements }\end{array}$ & $\begin{array}{l}\text { Basic steps of } \\
\text { modeling }\end{array}$ & $\begin{array}{l}\text { Quality, } \\
\text { context, and } \\
\text { characteristics } \\
\text { of the model }\end{array}$ & $\begin{array}{l}\text { Responsible } \\
\text { specialist }\end{array}$ & $\begin{array}{l}\text { Supply chain } \\
\text { and its parts. }\end{array}$ & $\begin{array}{l}\text { Requirements } \\
\text { for } \\
\text { changing/upda } \\
\text { ting the model }\end{array}$ \\
\hline Physical & $\begin{array}{l}\text { Information } \\
\text { system } \\
\text { requirements }\end{array}$ & $\begin{array}{l}\text { Information } \\
\text { technology }\end{array}$ & Databases & $\begin{array}{l}\text { Responsible } \\
\text { specialist }\end{array}$ & Departments & $\begin{array}{l}\text { Work } \\
\text { schedule }\end{array}$ \\
\hline Realization & $\begin{array}{l}\text { Implementation } \\
\text { goals }\end{array}$ & $\begin{array}{l}\text { Project } \\
\text { management } \\
\text { methodology } \\
\text { for } \\
\text { implementation }\end{array}$ & $\begin{array}{l}\text { Information } \\
\text { exchange } \\
\text { channels }\end{array}$ & $\begin{array}{l}\text { Implementation } \\
\text { team }\end{array}$ & $\begin{array}{l}\text { Scope of } \\
\text { improvements }\end{array}$ & $\begin{array}{l}\text { Horizon of } \\
\text { implementation }\end{array}$ \\
\hline
\end{tabular}

Each level below supports and details the previous level using its own unique perspective. For each level, the "why" column defines its goals and objectives, the "how" column defines the main tools for implementing these goals and objectives, the "what" column describes the information used for this purpose, the "who" column describes, in addition to the customers of the information, the roles of users, the "where" column indicates the location, the "when" column describes the time characteristics of the activity.

Due to the high relevance of the modular principle of design and development, including information systems, the upgraded scheme considers the option of configuring existing information solutions to solve the problems of planning and development of these systems (see physical level). If necessary, the proposed scheme can be used for new software applications developed from scratch.

The application of the developed scheme is considered on the example of a stripped-down description of one of the target processes of integrated supply chain planning - tactical supply chain planning or master planning (Stadtler and Kilger, 2008).

\section{Results}

\subsection{Conception level}

Why:

Defining the portfolio of orders (forecast and actual) and the range of products that allow the company to move in the directions set by the strategy and making sure interconnection of strategic plan with operational plans.

How: tactical supply chain planning process.

What:

- Input

- sales forecast;

○ supply chain model.

- Output

- sales plan, including optimal assortment.

Who: Planning unit, management, and other stakeholders. 
Where: Leading company.

When:

- Planning horizon: up to 18 months.

- Planning interval: month, week, example, next month-broken down by decades, next quarterbroken down by months, then-by quarters.

- Frequency of replanning: example, weekly, monthly.

\subsection{Process level}

Why:

The key objectives of the process are to ensure:

- realistic and economically reasonable plans;

- integrity of the supply chain view;

- optimality (possibility of end-to-end multi-criteria optimization);

- performance (reduction of planning time, change in the balance of work time of specialistsincrease in the share of time for scenario analysis of plans).

How / When / What:

The process of tactical supply chain planning within the SCOR model (Sergeev, 2005, 2015) is described in the process of sP1 Supply chain planning (Figure 1).

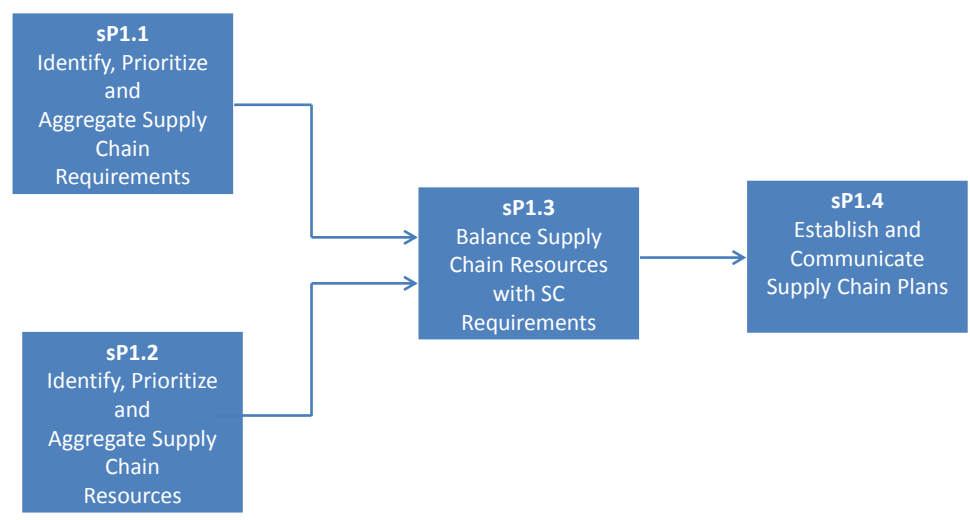

Figure 1. sP1 Supply chain planning process

As noted by Sergeev (2015) for the practical use of the SCOR model, further detailing of the threelevel model of SCOR processes is necessary to the next levels, where companies / industries develop specific methods of supply chain management.

An improved detailed process of tactical supply chain planning that takes into account the needs and specifics of metallurgical production is presented in figure 2. Departments do not prepare isolated plans. Instead they provide initial information for the modeling.

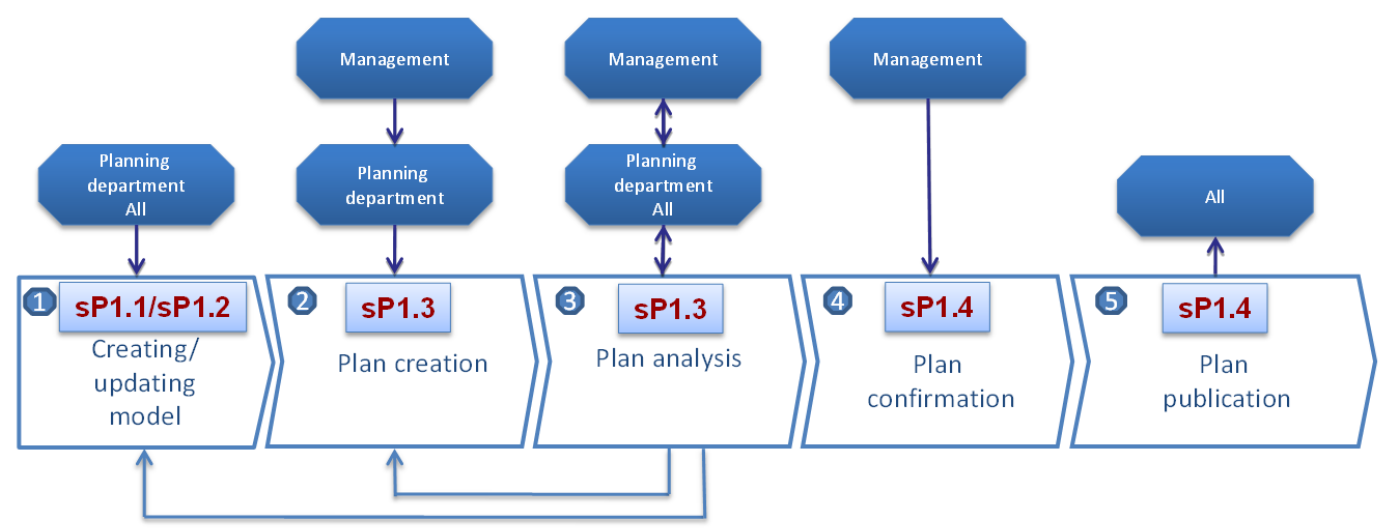

- Rolling 18-month planning with monthly replanning

- What-if analysis

Figure 2. Diagram of an improved tactical supply chain planning process linked to SCOR processes 
Planning cycle in this case is as follows.

When: Stage 1. Creating / updating a model.

Who: Planning unit, all departments.

How: Updating metadata and dynamic data.

What: As part of the metadata update, a description of the supply chain is being prepared (workshops, units; warehouses, metal depots; suppliers; finished and semi-finished products; technological routings, specifications with consumption coefficients - Bill of Material; transport links). The parameters of these elements are described: characteristics of resources (run rates of resources or duration of operation); warehouses constraints (maximum amount of materials); constraints on the production of a product mix, etc.

As part of the dynamic data update, data are updated on demand for products and prices (type of product, quantity, price); raw material prices and supplier capabilities (type of raw material, supplier, price, maximum quantity of delivery, delivery time, etc); production costs in relation to the routing rubles per ton; the level of initial, final, safety stocks reserves, if provided; availability of resources (hours), taking into account repairs, etc.

When: Stage 2. Building plan scenario.

Who: Company management, planning unit.

How: It is a usual practice when first plan is created with unlimited capacities. That allows finding bottlenecks thus defining requirements for additional resources to fulfill the demand. Then constraints are taken into account (both hard and soft) with different optimization criteria. Optimization takes place within the framework of modeling (building plan scenario) in planning tool.

What: Standard reports on the results of modeling are: sales (product, quantity, customer (or market) - price); purchase (raw materials, supplier, quantity, price); production (resource, semi-finished product, quantity); equipment usage (resource, planned loading in hours, percentages, tons, deviation from the target level); transportation (material, departure from, arrival to, quantity, transportation mode); inventory (storage location, material, stocks at the beginning of the interval, receipt, departure, balances at the end of the interval); economic performance (revenue, costs, total profit, unit profit).

When: Stage 3. Plan analysis.

Who: Company management, planning unit, all departments.

How: The variants of the plan are analysed taking into account standard indicators and is coordinated with stakeholders. In case of disagreement, the plans are adjusted, additional options are created by varying soft constraints and optimization criteria, and by changes to the input data.

It should be noted that according to the best practice, the process of rescheduling technically with all the data takes a few minutes.

What: Optimization criteria can include the following parameters: meeting demand in tons; minimum / maximum equipment load; minimizing the use of alternative routings; minimizing inventory; optimizing profits; minimizing costs; a combination of criteria.

When: Stage 4. Approval of the plan.

Who: Company management.

How: The final decision in favour of the most appropriate scenario for the company's development in the medium-term horizon is made by the management.

What: The most appropriate scenario for the company's development in the medium term.

When: Stage 5. The publication of the plan.

Who: All departments.

How: As a result of approval of the plan it is accepted as target for the set planning horizon and is brought to all interested departments.

What: Approved plan for the specified planning horizon.

Where: Supply chain and its part.

\subsection{Logical level}

Why:

According to many sources the most important requirements for any model are: adequacy; accuracy; universality; reasonable cost-effectiveness.

How:

The modeling process consists of the following main steps (Solodovnikov, 2017): creating a supply chain model, optimizing the model, interpreting of the modeling results (see figure 3). 


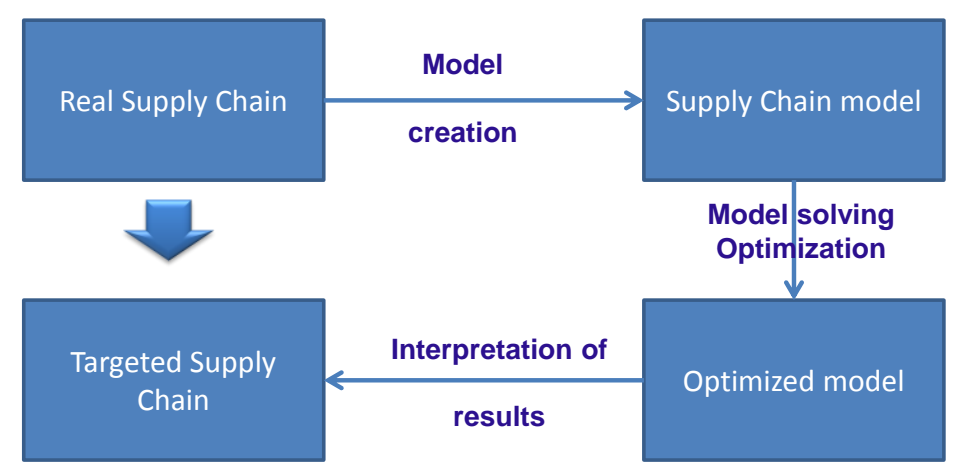

Figure 3. Modeling process

Model optimization is finding the best solution for the specified criteria respecting of the existing constraints. Examples of objective functions are: maximum marginality, maximum revenue, etc. The optimization algorithm is selected based on characteristics of the problem.

\section{What:}

The success of the solution of the planning problem is largely defined at the stage of formalization of the problem (definition of characteristics of the model).

The supply chain model is a simplified representation of the actual supply chain consisting of:

- supply chain objects (production, warehouses, markets, suppliers);

- links among these objects;

- conversion/transfer processes and resources (production, transportation);

- material and cash flows;

- model attributes and constraints.

Linear and mixed integer programming technologies are often applied in modeling of economic systems (Shapiro, 2006).

An example description of the mathematical model of the supply chain of a coal holding is given in the article Bendikov, Mishchenko, Solodovnikov (2019).

It should be noted that, in contrast to the scientific approach, the text-graphic description of the model is widely used in practice. That is, a separate document is developed or a separate section of the general document on the design of the solution is dedicated to this.

Who: Planning specialist.

Where: Supply chain and its parts.

When: It is defined based on requirements for changing/updating the model.

\subsection{Physical level}

Why:

The key requirements for the information system of tactical planning for the metallurgical enterprise are:

- a holistic view of the supply chain with modeling of material and cash flows (in terms of variable costs);

- taking into account the specifics of metallurgical processes in modeling;

- end-to-end multi-criteria layer-by-layer optimization of the company's activities.

How:

Table 3 shows a list of key international SCM vendors with international implementation experience in metals.

Table 3. This is an example of a Table

\begin{tabular}{|l|l|}
\hline Vendor & Solution \\
\hline JDA Software & Supply Chain Planner \\
\hline LOGIS & Master Planner \\
\hline OM Partners & Planner \\
\hline PSI Metals/Broner Metals (part of PSI) & Business Optimizer \\
\hline SAP & Supply Network Planning \\
\hline Quintiq & $\begin{array}{l}\text { Macro Planner } \\
\text { Company Planner }\end{array}$ \\
\hline
\end{tabular}


What: Documentation of the solution - structure of the database.

Who: Owner of the model, system administrator.

Where: SCM department, IT department.

When: It is determined by the system availability requirements, operating rules, user instructions.

\subsection{Realization level}

Why:

Implementation of tactical planning of supply chains of ferrous metallurgy enterprises.

How:

Practical experience of implementation shows that the implementation of tactical planning of supply chains of ferrous metallurgy enterprises is most effective when using a project approach with a fixed budget and deadlines. An alternative approach based on the time and material approach is rarely used and usually for a small amount of work.

A project approach with a fixed budget and deadlines, however, requires a particularly careful approach to project management, both on the part of the contractor and the customer.

Summarizing the successful experience of implementing integrated planning projects allowed identifying the key provisions of the improved project management methodology. This methodology is based on the concept of regular task setting by the contractor for the customer's project team with clearly defined deadlines. Implementation of these tasks should ensure timely achievement of intermediate project goals.

The use of an improved project management methodology with a fixed budget and time frame implies the following.

1. The contractor is responsible for achieving the results specified in the contract no later than the specified time within the agreed budget. Acceptance procedures, agreed in advance, allow objectively assessing the achievement of project results. The project management authority is on the contractor's side (the right to assign tasks to the customer's team).

2. The customer is responsible for the necessary level of assistance on the project, namely: performing the tasks for which the customer is responsible on the project (preparing and providing data, changing processes, etc.). If the customer fully fulfills its obligations in terms of scope and timing, in this case, the responsibility for the timing of the project results lies entirely with the contractor. However, in case the customer breaches its obligations (delayed deadlines), contractor shall be entitled to: 1) increase the deadline of the results of the project in proportion to the number of overdue days of the customer 2) increase the cost of the project in proportion to the value of the number of days of delay by the customer.

If there was a delay on the customer's side and the contractor came to the conclusion that this delay hinders him in the completion of the stage and the entire project, and if there had not been a significant delay of the customer before, the contractor is obliged to provide the customer with the following options (the time for decision-making by the customer is limited):

A. Compliance with time and cost. The obligation of the contractor to provide the result (to perform the acceptance procedure) is no longer valid, instead of it comes into force the obligation to provide at the place of work qualified resources in the amounts established by the contract-the cost does not change.

B. Compliance with the result. Achieving the planned result requires additional allocation of resources of the contractor-this entails a change in the timing and cost of the project.

What: Project charter, and other project management documents.

Who: implementation team.

Where: It is defined based on scope of the project.

When: project implementation plan.

\section{Conclusions}

Many researchers consider the Zachman framework to be an interdisciplinary one, with an impact that goes far beyond it. Taking into account the continuing trend of business digitalization, including in the field of integrated supply chain planning, the use of this concept allows us to solve the important scientific problem of systematization and structuring of industry methodologies. The adapted model described in the paper, which was used to describe the structure of the industry methodology of integrated supply chain planning of ferrous metallurgy companies (Solodovnikov, 2017), in practice proves the effectiveness of the proposed approach. 


\section{References}

1. Bendikov, M.A., Mishchenko, A.V., Solodovnikov, V.V. (2019) Ekonomiko-matematicheskij podhod $\mathrm{k}$ takticheskomu planirovaniyu cepi postavok geograficheski raspredelennyh promyshlennyh predpriyatij (na primere ugol'nogo holdinga). Logistics and supply chain management, 3.

2. Gorshkov, S. (2016) Vvedenie v ontologicheskoe modelirovanie. Moscow, LLC "TriniData»

3. Harmon, P. (2007) Business Process Change. A Guide for Business Managers and BPM and Six Sigma Professionals. Second Edition. Burlington, Morgan Kaufmann Publishers.

4. O'Rourke, C., Fishman, N., Selkow, W. (2003) Enterprise Architecture Using the Zachman Framework. Boston, MA: Course Technology.

5. Sergeev, V.I. (2005) Rekomenduemaya model' operacij v cepyah postavok - SCOR-model'. Logistics and supply chain management, 2.

6. Sergeev, V.I. (2015) Upravlenie cepyami postavok. Moscow, Uright.

7. Solodovnikov, V.V. (2017) Metodologiya integrirovannogo planirovaniya cepej postavok promyshlennyh predpriyatij (na primere kompleksov chernoj metallurgii). Moscow, PSC "ITKOR".

8. Solodovnikov, V.V. (2017) Modeli integrirovannogo planirovaniya dlya metallurgicheskih predpriyatij. RISK, 4.

9. Shapiro, J. (2006) Modeling The Supply Chain, 2nd edition. US: Cengage India.

10. Shteingart, E.A., Burmistrov, A.N. (2016) Obzor i sravnitel'naya harakteristika metodologij razrabotki arhitektury predpriyatij. Scientific-Technical News SPbGPU. Economic Sciences, 3.

11. Sessions, R. (2007) A Comparison of the Top Four Enterprise-Architecture Methodologies https://web.archive.org/web/20080409195426/http://msdn2.microsoft.com/enus/library/bb466232.aspx

12. Sessions, R. (2007) Interview with John Zachman by Roger Sessions. Perspectives of the International Association of Software Architects, Issue 6.

13. Stadtler, H., Kilger, C. (2008) Supply Chain Management and Advanced Planning. Concepts, Models, Software, and Case Studies. Berlin:Springer.

14. Zachman, J.A. (1987) A Framework for Information Systems Architecture. IBM Systems Journal, 26(3).

15. Zachman, J.A., Sowa J.F. (1992) Extending and Formalizing the Framework for Information Systems Architecture. IBM Systems Journal, 31(3). 